\title{
Kymmenes vuosi ikääntyvien yliopistotoimintaa Suomessa
}

Ikääntymisen myötä oppimisen muodot muuttuvat, mutta kyky oppia säilyy läpi elämän. Nuori muistaa paremmin yksittäisiä asioita, ikäihminen taas hahmottaa helpommin kokonaisuuksia ja asioiden keskinäisiä suhteita. Ikääntyvien yliopistotoiminnassa tieteellinen tieto ja elämänkokemus kohtaavat.

Ikääntyvien yliopistotoiminnan kansainväliset juuret ovat 1970luvun alkupuolella. Ranskassa Toulousen yliopistossa alkoi vuonna 1973 opiskelumuoto, jonka tavoitteena oli järjestää mahdollisuus korkeakoulutasoiseen opiskeluun ikääntyneille, eläkeikäisille tai työelämästä syrjäytyneille. Uusi idea levisi nopeasti eri puolille maailmaa ja samalla muuntautui monikirjoiseksi toiminnaksi niin toteutusmuodoiltaan kuin hallinnoltaankin.

Suomeen ikääntyvien yliopistotoiminta juurtui vuonna 1985, jolloin Jyväskylän yliopistossa käynnistyi "Ikääntyvien yliopisto" ja Helsingin yliopistossa "Ikäihmisten yliopisto". Uusi toiminta löysi paikkansa avoimen yliopisto-opetuksen erityismuotona. Se oli luonteva ratkaisu, sillä avoin yliopisto-opetus on Suomessa osoittautunut yliopistollisen opetuksen kokeilu- ja kehittämiskentäksi ja uusien ideoiden toteutuspaikaksi.
Kun kymmenes toimintavuosi on alkamassa, on ikääntyvien yliopistotoiminta jo laajentunut valtakunnalliseksi. Nykyään tätä toimintaa on kahdeksassa yliopistossa (Helsinki, Joensuu, Jyväskylä, Kuopio, Lappi, Oulu, Tampere ja Turku). Toiminnan johdossa on jokaisessa yliopistossa tätä varten nimetty johtoryhmä, johon kuuluu sekä yliopiston että opiskelijoiden edustajia. Yliopistot perustivat vuonna 1989 Ikääntyvien yliopistotoiminnan neuvottelukunnan, jossa on edustus kaikista edellä mainituista yliopistoista.

\section{Miksi opetusta tietylle ikäryhmälle?}

Kansainvälinen termi "Kolmannen iän yliopisto" liittyy hahmotukseen ihmisen neljästä ikäkaudesta: ensin on lapsuus ja nuoruus, sitten tuotantoon liittyvä työikä, työelämän jälkeen itsensä toteuttamisen aika ja viimeiseksi riippuvuuden ja raihnaisuuden aika. Ikääntyvien yliopistotoiminnan perusideana on ollut tarjota korkeakoulutasoinen opiskelumahdollisuus vireille ja aktiivisille eläkeikäisille, joilla on aikaa, kykyä ja intoa vaativaan opiskeluun.

Perinteisen avoimen yliopisto-opetuksen puitteissa on tehty havainto, että ikääntyneet ovat erittäin pieni osallistujaryhmä, vaikka osallistumiselle ei mitään yläikärajaa olekaan. Kun heiltä itseltään satunnaisesti on kysytty syytä tähän, on yleensä vastauksena, että aiheet kyllä kiinnostaisivat, mutta arvosanakeskeisyys ja suorituspainotteisuus tekee opiskelun liian kaavamaiseksi ja turhauttavaksi.

Ikääntyvien yliopistotoiminnalla on näin ollen ollut tavallaan selvä tilaus, koska siinä alusta pi- 
täen ei ole korostettu tenttejä eikä opintoviikkoja, vaan tietoa, oppimista ja ymmärtämistä. Oikeastaan ikääntyvien yliopistotoiminnassa on palattu vanhan sivistysyliopiston ideaan. Tieto itsessään ja halu oppia ovat tärkeämpiä kuin opintosuoritukset.

Ikääntyneiden ryhmä ei ole suinkaan homogeeninen, saattaahan siellä osanottajien ikäerokin lähennellä neljääkymmentä vuotta. Myös pohjakoulutus vaihtelee suuresti, sillä rajoituksia ei sen suhteen aseteta, kuten ei muussakaan avoimessa yliopisto-opetuksessa. Suuria eroja on luonnollisesti myös työelämän kokemuksissa ja koko elämänhistoriassa.

\section{Mitä asioita ikäihmiset haluavat oppia?}

Ikääntyvien yliopistotoiminnan puitteissa järjestettävä opetus on aina korkeakoulutasoista. Kuitenkin opiskelijat itse vaikuttavat kurssiensa sisältöihin ja toteutukseen yhteissuunnittelun avulla. Tuloksena on monimuotoiseksi ja rikassisältöiseksi kasvanut toiminta, jota on vaikea lyhyesti luonnehtia.

Yleisin ikääntyvien yliopistotoiminnan muoto on alusta lähtien ollut monitieteinen keskusteleva luento-opetus, joka kootaan opiskelijoiden itsensä valitseman teeman ympärille. Luennoitsijoina ovat yliopistojen parhaat asiantuntijat, jotka useimmiten nauttivat suuresti harvinaislaatuisesta vuorovaikutuksesta kuulijoihin, joilla on elämänkokemuksen kautta omakohtaista perehtyneisyyttä käsiteltäviin asioihin tai niiden taustoihin.

Luentosarjojen aiheet vaihtelevat yliopistoittain ja vuosittain. Ehkä vähiten käsitellään ikääntymistä ja eniten aivan uusia, päivänpolttavia asioita. Niinpä näinä aikoina ovat esillä kansainväliset kysymykset mm. kulttuuritieteiden, historian ja maailmanpolitiikan näkökulmasta. Samoin perehdytään EU-asioihin, Baltian maiden vaiheisiin ja tulevaisuudentutkimukseen. Myös psykologiset ja luonnontieteelliset teemat ovat suosittuja. Opetusta järjestetään myös ruotsiksi.

Ikääntyvien yliopistotoiminnassa on runsaasti muitakin toimintamuotoja. Näistä mainitta- koon seminaarityöskentely, jossa esimerkiksi kerätään jonkin asuinalueen paikallishistoriaa ja järjestetään aiheesta näyttely. Muutamat seminaariryhmät ovat osallistuneet tutkimusprojekteihin ja toiset taas perehtyneet kirjoittamiseen ja tuottaneet antologian työnsä tuloksista. Lisäksi ikäihmiset tekevät runsaasti ekskursioita ja opintomatkoja opiskelunsa pohjalta.

Kansainväliset yhteydet ovat alusta alkaen sävyttäneet ikääntyneiden yliopistotoimintaa. Suomalaiset yliopistot kuuluvat vuonna 1976 perustettuun Ikääntyvien yliopistojen kansainväliseen järjestöön (International Association of the Universities of the Third Age). Järjestön XVII maailmankongressi pidetään 12.-14.8. 1994 Jyväskylän yliopistossa. Kongressi on tarkoitettu sekä tutkijoille että opiskelijoille itselleen. Yleisteemana on "Vanhuuteen valmistautuminen". Kongressiin on jo tullut satoja ennakkoilmoittautumisia, joten luvassa on näkyvä ja merkittävä tapahtuma, joka samalla kertoo suomalaisten aktiivisuudesta ikääntyvien yliopistotoiminnan järjestämisessä.

\section{Mukana myös neljännen ikäkauden edustajia}

Yksi kiintoisimmista viimeaikaisista kokeiluista on ollut Helsingin yliopiston käynnistämä ikäihmisten yliopistotoiminta vanhusten palvelutaloissa ja hoitokodeissa. Tällöin on ajateltu niitä vanhuksia, jotka olosuhteittensa tai fyysisten rajoitustensa vuoksi eivät voi tulla Ikäihmisten yliopiston kokoontumispaikkoihin. Näin on samalla saatu mukaan uusi opiskelijaryhmä, joka itse asiassa edustaa ns. neljättä ikäkautta, riippuvuuden ja raihnaisuuden kautta.

Helsingin yliopiston Ikäihmisten yliopistossa pidettyjä luentoja on nauhoitettu kaseteille, ja kokoontumiset vanhusten palvelutaloissa ja hoitokodeissa on järjestetty näiden kasettien varaan. Yliopiston puolesta on joka kokoontumisessa paikalla kurssisihteeri, joka tuntee aihepiirin ja toimii ryhmän vetäjänä ja keskustelun johdattelijana. Osanottajat voivat kuunnella kasetteja ja tutustua niihin liittyvään oheismateriaaliin myös kokoontumisten jälkeen omana aikanaan. 
Tulokset ovat olleet rohkaisevia ja kannustavia. Jokaisessa pienryhmässä on haluttu ehdottomasti jatkaa opiskelua ensimmäisen kasettiluentosarjan päätyttyä. Korkeakoulutasoinen opiskelu on siis löytänyt paikkansa myös hoitolaitoksen seinien sisällä.

\section{Hyötyä vai harrastusta}

Vaikka ikääntyvien yliopistotoiminta on laajentunut valtakunnalliseksi, on se kuitenkin pysynyt suhteellisen pienimuotoisena. Vuonna 1993 tähän toimintaan osallistui Suomessa runsaat 2000 opiskelijaa. Erilaisia opintoryhmiä toimi yhteensä noin 60 , ja ne kokoontuivat 30 eri paikkakunnalla. (Vrt. Ruthin, Tikkasen \& Kuusisen artikkeli sivu , toim. huom.).

Ikääntyvien yliopistotoiminnan kasvun rajat eivät asetu opiskeluhalukkuuden, vaan taloudellisten resurssien perusteella. Toiminta rahoitetaan etupäässä valtion ja kuntien määrärahoilla, jotka näinä aikoina supistuvat kaiken harrastustavoitteisen opiskelun suhteen. Opiskelumahdollisuuksien järjestämisessä ikääntyville ei ole helppoa nähdä samanlaista välitöntä hyötyä kuin vaikkapa työvoimapoliittisen aikuiskoulutuksen järjestämisessä. Hyöty kuitenkin tulee ikääntyvien aktiivisuuden ja omaehtoisuuden lisääntymisenä sekä henkisen ja fyysisen vireyden kasvuna. Tätä tulosta on vaikea muuttaa markoiksi.

\section{Suhtautuminen vanhuuteen}

Suhtautumista vanhoihin ihmisiin sävyttää usein holhoava asenne. Vanhus asetetaan passiiviseen rooliin ja häntä koskevat ratkaisut tehdään muiden toimesta. Kärjistäen voi sanoa, että vanhuksesta tehdään asiantuntijatarkkailun kohde: häntä määrittelevät tutkijat, lääkärit, sosiaalityöntekijät, papit jne. Kun vanhuksille järjestetään toimintaa, on siinä usein viihdyttämisen tai terapian piirre.

Ikääntyvien yliopistotoimintaa kannattelee toisenlainen suhtautuminen vanhuuteen. Se perustuu näkemykseen siitä, että ihminen on elämänsä jokaisessa vaiheessa oppiva, reagoiva, omaan elämäänsä ja ympäristöönsä vaikuttava, tutkiva, ratkaisuja tekevä ja kehittyvä. Tällöin hän myös ikääntyneenä itse ratkaisee halukkuutensa opiskeluun sekä opintojensa aihepiirin ja tason. Opiskelijana hän on täysivertainen niin luennoitsijoiden kuin yliopiston suunnittelijoiden ja kurssisihteereiden kanssa.

Opiskelijoilta saatu palaute kertoo, että edellä kuvattu asenne on osanottajille itselleen arvokas lähtökohta. Kommentit ovat satuttavia:

- Kun on jäänyt eläkkeelle, ihmisten asennoituminen on muuttunut. Puhutaan niinkuin ei ymmärtäisi asioita enää.

- Ihmiset ovat olleet vaativassa työelämässä. Sitten jäädään eläkkeelle. Mitenkä ihminen sillä hetkellä tulisi niin tyhmäksi, että hänelle pitäisi alkaa leperrellä kuin lapselle.

- Tämä on ensimmäinen kerta, kun minut eläkkeellä ollessa on otettu aivan täydestä.

- Tärkeintä oli kokemus, että me olimme saaneet olla mukana jossakin ihan oikeassa.

Nopeasti muuttuvassa yhteiskunnassa jokainen ikäryhmä tarvitsee laaja-alaista koulutusta maailman ymmärtämiseksi ja muutoksen hahmottamiseksi. Elinikäisen koulutuksen näkökulmasta ikääntyneiden yliopistotoiminta on arvokas ja merkityksellinen tehtävä. Dosentti William Copeland, joka on paljon opettanut Helsingin yliopiston Ikäihmisten yliopistossa, kiteyttää toteamuksen: "Ei koulutus ole mitään luksusta tai ylimääräinen namu joka annetaan tai ei anneta, vaan se kuuluu tasapainoisen, hyvän ja oikeudenmukaisen yhteiskunnan peruslähtökohtiin. Ihmisen tulee saada vanhanakin arvonsa mukaista kohtelua myös koulutuksen osalta."

Helsingin yliopiston Ikäihmisten yliopiston vanhin opiskelija on Kannelkotisäätiön palvelukodissa asuva 102-vuotias Aino Durcbman. Hän totesi omista opiskelumahdollisuuksistaan, ettei enää pysty lukemaan, mutta sen sijaan jaksaa kuunnella kasettiluentoja. Hän jatkoi: "Kun en öisin saa unta, minä ajattelen, ja ajatteleminen on hyvin kehittävää.” Kun 102-vuotias opiskelija haluaa yhä toteuttaa omaa kehitystehtäväänsä, antaa hän samalla vakuuttavan todisteen siitä, että ihmisen koko elämänkaari voi olla kasvun kaari. 